\title{
The Effect of Increasing Humic Acid Applications on Some Nutrient Contents of Cress (Lepidium sativum L.) Plant
}

\author{
Aydın Adiloğlu' ${ }^{*}$, Sevinç Adiloğlu ${ }^{1}$, Mehmet Rüştü Karaman², Yusuf Solmaz', \\ Funda Eryilmaz Açikgöz ${ }^{3}$
}

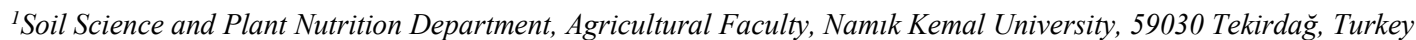

${ }^{2}$ Department of Medical and Aromatic Plants, Sultandağı Vocational School, Afyon Kocatepe University University, 03650 Afyon, Turkey ${ }^{3}$ Department of Plant and Animal Production, Vocational Collage of Technical Science, Namık Kemal University, 59030 Tekirdağ, Turkey

A R T I C L E I N F O
Research Article
Received 21 September 2017
Accepted 15 December 2017

Keywords:

Humic acid

Cress (Lepidium sativum L.)

Plant nutrient

Macro element

Trace element

*Corresponding Author:

E-mail: a_adiloglu@hotmail.com

\begin{abstract}
A B S T R A C T
This research was done to determine the effect of increasing Humic acid application on some nutrient element contents of cress (Lepidium sativum L.) plant. For this purpose according to randomize block experimental design, an experiment was done with three replications in greenhouse conditions. Cress plant seed was sowed $1.5 \mathrm{~g} / \mathrm{m}^{2}$. Four humic acid doses (I. dose: $0 \mathrm{~mL} / \mathrm{m}^{2}$, II. dose: $8 \mathrm{~mL} / \mathrm{m}^{2}$, III. dose: $16 \mathrm{~mL} / \mathrm{m}^{2}$ and IV. dose: 24 $\mathrm{mL} / \mathrm{m}^{2}$ ) were applied to cress plant. Then cress plants were harvested 30 days after planting. Dry matter yield and some nutrient (N, P, K, Ca, Mg, S, Fe, Cu, $\mathrm{Zn}$ and $\mathrm{Mn}$ ) contents of plants were determined. According to the results, important increases some nutrient element contents of plants were determined with increasing humic acid applications. These increases were found 1 . dose $5.52 \%$, and 4 . dose $6.04 \%$, for $\mathrm{N}$ element, respectively. Other macro elements $\mathrm{P}(0.70 \%$, and $0.82 \%)$; $\mathrm{K}(6.85 \%$, and 7.67\%); $\mathrm{Ca}(1.72 \%$, and $2.01 \%)$; $\mathrm{Mg}(0.13 \%$ and $0.15 \%)$ and $\mathrm{S}(1.04 \%$, and $1.17 \%)$, respectively. Some micro element $(\mathrm{Fe}, \mathrm{Cu}, \mathrm{Zn}$ and $\mathrm{Mn})$ contents of cress plant, 1. dose: 89.86, 9.59, 59.50 and 56.20; 4. dose: 102.17, 11.03, 67.67 and $76.63 \mathrm{mgkg}^{-1}$, respectively. These increases were found statistically significant at the level of $5 \%$ for each nutrient element, except $\mathrm{Mg}$.
\end{abstract}

DOI: https://doi.org/10.24925/turjaf.v6i2.199-202.1566

\section{Introduction}

Nowadays it is stringent to receive more products from per unit of agricultural area in order to fulfill the increasing population's need for nutrition and food, which in its turn causes the need for inorganic fertilizer implementation. The excessive and unconscious use of inorganic fertilizers in agriculture has caused serious pollution problems in soil and water sources, as well as various health problems.

Cress (Lepidium sativum L.) has been a member of brassicaceae family whose leaves are edible. It can be cultivated in every part of the world, especially in Asian countries, Europe and America (Diwakar et al., 2010; Zhan et al., 2009).

Cress (Lepidium sativum L.) is sensitive to blooming and has short vegetation; it can be grown in every period except in hot summer season. It is produced for commercial purposes in the Aegean, Mediterranean and Marmara regions in Turkey. In recent years it has been grown under greenhouse in winter season (Yanmaz et al., 2010).
Cress, whose fresh leaves are consumed as salad and garniture, is a very popular vegetable for both consumers and producers for its vitamin, mineral and anticarcinogenic contents (Tuncay et al., 2011).

Generally, in order to reach higher yield and maximum growth, the inorganic fertilizers are highly preferred as the main source of plant's nutrient elements; however, it has use excessive (Adediran et al., 2004; Naeem et al., 2006).

It has been known that especially the greencomponent plants respond positively to inorganic fertilization, nevertheless, nitrogen implementation affects the yield positively to some extent (Karaman et al., 2012a).

Scientists, who are in search for a solution to polluted natural soil and water resources as a result of the excessive use of chemical fertilizers, have pointed out that the use of organic fertilizers should be increased. Because besides its advantages as fertilizer material and nutrient source, organic fertilizers can also heal the quality deterioration of soil and water resources caused by 
inorganic fertilizers. In recent years, the use of organic fertilizers has been common especially in vegetable cultivation (Adiloğlu et al., 2016).

Organic fertilizers have considerably been used in plant cultivation in recent years. These fertilizers provide significant improvement in plant yield and quality. In a research conducted to investigate this (Doğru et al., 2012), the effects of 50,100,200, 400 and $600 \mathrm{mg} / \mathrm{kg}$ humic acid application to corn plant on its fresh and dry weight, and the amount of soluble proteins are analyzed. Significant increases in the biological characteristics of the corn plant are observed after more than $200 \mathrm{mg} / \mathrm{kg}$ dose of humic acid is applied.

According to the scientists, the results of scientific researches indicate that humic acid application increases the micronutrient availability depending on the chemical interactions of humic substances in soil and regulates the micronutrient absorption of plants (Karaman et al., 2012b).

In this research, the effects of the increasing doses of humic acid application on cress's (Lepidium sativum L.) some macro and micro nutrient element components have been explored.

\section{Material and Methods}

The experiment was carried out in November and December, 2014, Tekirdag city $\left(40^{\circ} 98^{\prime} \mathrm{N}, 27^{\circ} 48^{\prime} \mathrm{E}\right)$ using high tunnel greenhouse covered by polyetilen (PE) with UV additive, which belongs to Namık Kemal University, Vocational School of Technical Sciences, Plant and Animal Production Department. In the experiment, organic cress seeds were used.

The experiment is designed according to the randomized block design with 3 replicates. Plantation is completed as $1.5 \mathrm{~g} / \mathrm{m}^{2}, 4$ doses $\left(1^{\text {st }}\right.$ dose: $0 \mathrm{~mL} / \mathrm{m}^{2}, 2^{\text {nd }}$ dose: $8 \mathrm{~mL} / \mathrm{m}^{2}, 3^{\text {rd }}$ dose: $16 \mathrm{~mL} / \mathrm{m}^{2}$ and $4^{\text {th }}$ dose: 24 $\mathrm{mL} / \mathrm{m}^{2}$ ), and the humic acid application and plantation are conducted simultaneously, because the vegetation period, which is 30 days, is very short. $100 \mathrm{ppm} \mathrm{N}\left(\mathrm{NH}_{4} \mathrm{NO}_{3}\right.$ form) and $80 \mathrm{ppm} \mathrm{P}_{2} \mathrm{O}_{5}\left(\mathrm{KH}_{2} \mathrm{PO}_{4}\right.$ form) of solution is applied to the plants with the plantation. The plants are harvested 30 days after of seed sowing. Single harvest was done in the experiment the general view of the experiment is presented in the Figure 1.

Some chemical characteristics of humic acid which has been used in the experiment and some chemical and physical characteristics of the research area soil are presented in the Table 1 and 2 .

According to the Table 2, the experiment area soil is identified as having neutral reaction, no salt, medium lime, organic matter insufficiency, medium available phosphorus content and exchangeable potassium, $\mathrm{Mg}$ and available $\mathrm{Fe}, \mathrm{Cu}, \mathrm{Zn}$ and $\mathrm{Mn}$ content were sufficient.

The harvested plants are brought to the laboratory immediately, plants were washed with distilled water two times, they were dried in $65^{\circ} \mathrm{C}$ drying-oven till their weight get stabilized, they were ground and prepared for the analysis. Nitrogen content of the samples was done with Kjeldahl method, and $\mathrm{P}, \mathrm{K}, \mathrm{Ca}, \mathrm{Mg}, \mathrm{S}, \mathrm{Fe}, \mathrm{Cu}, \mathrm{Zn}$ and $\mathrm{Mn}$ were determined by ICP-OES (Kacar and İnal 2010).

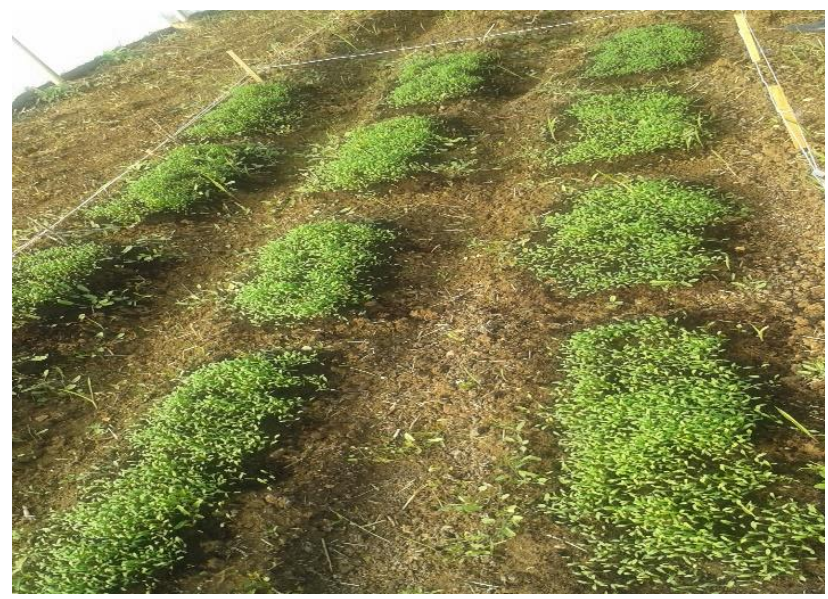

Figure $1 \mathrm{~A}$ general view from cress experiment (Original)

Table 1 Some chemical properties of humic acid (w/w) used in experiment

\begin{tabular}{l|c}
\hline \multicolumn{1}{c|}{ Property } & Value \\
\hline $\mathrm{pH}$ & $11-13$ \\
Organic matter $\%$, & 5 \\
Total hümic + fulvic acid, $\%$ & 12 \\
Soluble in water $\mathrm{K}_{2} \mathrm{O} \%$ & 3 \\
\hline
\end{tabular}

Table 2 Some chemical and physical characteristics of experiment area soil.

\begin{tabular}{l|c}
\hline \multicolumn{1}{c|}{ Soil property } & Analysis result \\
\hline $\mathrm{pH}$ & 6.75 \\
$\mathrm{EC} \mathrm{x} \mathrm{C}^{6}$ & 156 \\
$\mathrm{Lime}\left(\mathrm{CaCO}_{3}\right), \%$ & 6.20 \\
Organic matter, \% & 1.10 \\
$\mathrm{Ca}, \%$ & 0.73 \\
$\mathrm{P}_{2} \mathrm{O}_{5}, \mathrm{~kg} \mathrm{da}^{-1}$ & 12.10 \\
$\mathrm{~K}_{2} \mathrm{O}, \mathrm{kg} \mathrm{da}^{-1}$ & 63.41 \\
$\mathrm{Mg}, \mathrm{mg} \mathrm{kg}^{-1}$ & 320.60 \\
$\mathrm{Fe}, \mathrm{mg} \mathrm{kg}^{-1}$ & 8.95 \\
$\mathrm{Cu} \mathrm{mg} \mathrm{kg}^{-1}$ & 1.43 \\
$\mathrm{Zn}, \mathrm{mg} \mathrm{kg}^{-1}$ & 0.87 \\
$\mathrm{Mn}, \mathrm{mg} \mathrm{kg}^{-1}$ & 10.72 \\
\hline
\end{tabular}

\section{Results and Discussion}

The Effects of the Humic Acid Application on Cress (Lepidium sativum L.) Plant Some Macro Nutrient Element ( $N, P, K, C a, M g, S$ ) Contents

The effects of the increasing doses of humic acid application on cress's some macro nutrient element contents are given in the Table 3.

When Table 3 is examined, it can be observed significant increases (5\% degree) in N, P, K, Ca and S contents of cress plant with humic acid applications. However, even if the humic acid application provides an increase in the plant's $\mathrm{Mg}$ content, this increase is not considered significant.

In a research of Fagbenro and Agboola (1993), which is conducted by using teak plant (Tectona grandis L.) has similar results with the research mentioned previously, and significant increase is observed in $\mathrm{N}, \mathrm{P}, \mathrm{K}, \mathrm{Ca}$ and $\mathrm{Mg}$ components of teak with the increasing doses of humic acid. 
Table 3 The effect of humic acid application on some macro element (N, P, K, Ca, Mg, S) contents of cress plant, \%,*

\begin{tabular}{c|cccccc}
\hline Doses & $\mathrm{N}$ & $\mathrm{P}$ & $\mathrm{K}$ & $\mathrm{Ca}$ & $\mathrm{Mg}$ & $\mathrm{S}$ \\
\hline I & $5.52^{\mathrm{a}}$ & $0.70^{\mathrm{a}}$ & $6.85^{\mathrm{a}}$ & $1.72^{\mathrm{a}}$ & $0.13^{\mathrm{a}}$ & $1.04^{\mathrm{a}}$ \\
II & $5.54^{\mathrm{a}}$ & $0.72^{\mathrm{a}}$ & $7.00^{\mathrm{b}}$ & $1.79^{\mathrm{a}}$ & $0.14^{\mathrm{a}}$ & $1.08^{\mathrm{a}}$ \\
III & $5.93^{\mathrm{b}}$ & $0.78^{\mathrm{b}}$ & $7.37^{\mathrm{c}}$ & $1.90^{\mathrm{b}}$ & $0.15^{\mathrm{a}}$ & $1.09^{\mathrm{a}}$ \\
VI & $6.04^{\mathrm{b}}$ & $0.82^{\mathrm{b}}$ & $7.67^{\mathrm{d}}$ & $2.01^{\mathrm{b}}$ & $0.15^{\mathrm{a}}$ & $1.17^{\mathrm{b}}$ \\
\hline
\end{tabular}

*: The values mean of three replications, **: each element was evaluated individually and values in the same column with different letters are statistically significant at the level of $5 \%$.

Table 4 The effect of humic acid application on some micro element $(\mathrm{Fe}, \mathrm{Cu}, \mathrm{Zn}, \mathrm{Mn})$ contents of cress plant, $\mathrm{mg} \mathrm{kg}^{-1}$, *

\begin{tabular}{c|cccc}
\hline Doses & $\mathrm{Fe}$ & $\mathrm{Cu}$ & $\mathrm{Zn}$ & $\mathrm{Mn}$ \\
\hline I & $89.86^{\mathrm{a}}$ & $9.59^{\mathrm{a}}$ & $59.50^{\mathrm{a}}$ & $56.20^{\mathrm{a}}$ \\
II & $90.65^{\mathrm{a}}$ & $9.95^{\mathrm{b}}$ & $63.93^{\mathrm{b}}$ & $72.97^{\mathrm{b}}$ \\
III & $102.31^{\mathrm{b}}$ & $10.59^{\mathrm{c}}$ & $65.53^{\mathrm{c}}$ & $74.40^{\mathrm{b}}$ \\
VI & $102.17^{\mathrm{b}}$ & $11.03^{\mathrm{d}}$ & $67.67^{\mathrm{d}}$ & $76.63^{\mathrm{c}}$ \\
\hline
\end{tabular}

*: The values mean of three replications, **: each element was evaluated individually and values in the same column with different letters are statistically significant at the level of $5 \%$.

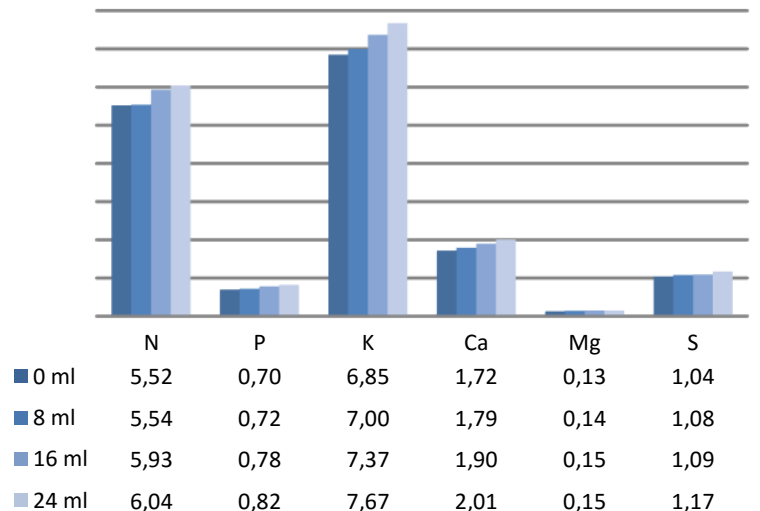

Figure 2 The effect of humic acid application on some macro element contents of cress plant

The effects of humic acid application on cress's some macro nutrient element contents are given in the Figure 2.

In a research (Çimrin et al., 2000), which is conducted by using corn plant, significant increase is observed in the $\mathrm{K}$ content of corn with the increasing doses of humic acid application.

The Effects of the Humic Acid Application on Cress (Lepidium sativum L.) Plant Some Micro Nutrient Element ( $\mathrm{Fe}, \mathrm{Cu}, \mathrm{Zn}, \mathrm{Mn}$ ) Contents

The effects of the increasing doses of humic acid application on cress's some micro nutrient element contents are given in Table 4.

When Table 4 is examined, it can be observed significant increases (5\% degree) in $\mathrm{Fe}, \mathrm{Cu}, \mathrm{Zn}$ and $\mathrm{Mn}$ contents of cress plant with humic acid applications.

In the experiment carried out by using tomato plant under greenhouse conditions (David et al., 1994), 0, 640, 1280 and $2560 \mathrm{mg} / \mathrm{L}$ doses of humic acid are applied to the plants. It has been proven that $\mathrm{Fe}, \mathrm{Cu}, \mathrm{Zn}$ and $\mathrm{Mn}$ nutrition contents significantly increase with the increasing doses of humic acid.

The effects of humic acid application on cress's some micro nutrient element contents are given in the Figure 3.

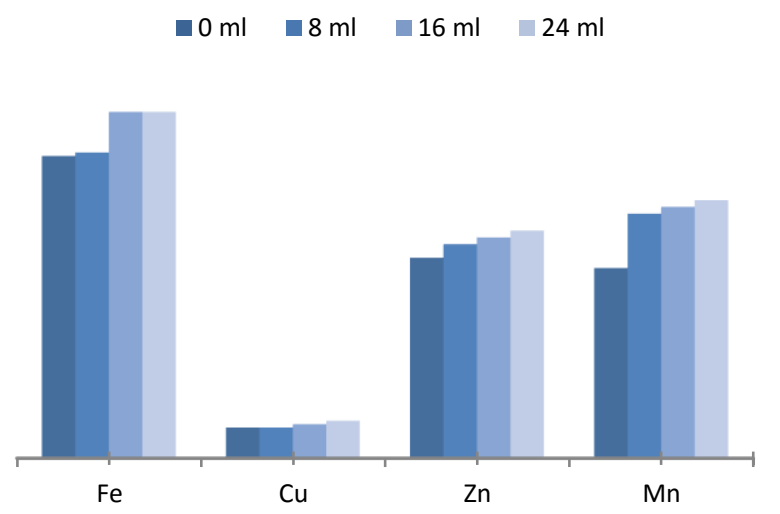

Figure 3 The effect of humic acid application on some micro element contents of cress plant

\section{Conclusion}

In this research which aims to investigate the effects of the increasing doses of humic acid application on cress plant's some macro and micro nutrient element contents, significant increases in cress's $\mathrm{N}, \mathrm{P}, \mathrm{K}, \mathrm{Ca}, \mathrm{Mg}, \mathrm{S}, \mathrm{Fe}, \mathrm{Cu}$, $\mathrm{Zn}$ and $\mathrm{Mn}$ nutrient elements have been identified compared to the control group. According to the data's, the increasing doses of humic acid application provide the increasing of cress plant's some macro and micro nutrient element contents. These increases have been considered important with 5\% statistical degree except for $\mathrm{Mg}$ nutrient element.

On the other hand, organic fertilizers and soil improvers, such as humic acid, have been commonly used in agriculture in recent years. As a consequence, the excessive and unconscious use of chemical fertilizers in agriculture has caused serious problems in the quality of agricultural products. Besides, most of the soils in our country have insufficient organic matter (Adiloğu and Sağlam, 2015; Adiloğlu and Karaman, 2015). The use of organic materials in agriculture, such as leonardite, in eliminating insufficiency of organic matter components and maintaining the productivity of soils is highly needed. 


\section{Competing Interests} exist.

Authors have declared that no competing interests

\section{References}

Adediran AJ, Taiwo BL, Akande OM, Sobule AR, Idowu JO. 2004. Application of organic and inorganic fertilizer for sustainable maize and cowpea yields in Nigeria. J. Plant Nutr. 27: 1163-1181.

Adiloğlu A, Karaman MR. 2015. Changing trendy of organic matter content in Trakya region soils between 1984 and 2013 years. KSU Journal of Natural Sciences, Special Issue 18 (3): 44- 48.

Adiloğlu A, Eryılmaz Açıkgöz F, Adiloğlu S, Solmaz Y. 2016. The effect of increasing amounts of aquaculture waste application on the some macro and micro nutrient element contents of salad plant (Lactuca sativa L. var. crispa) Journal of Tekirdağ Agricultural Faculty, 13 (2): 96-101.

Adiloğlu S, Sağlam MT. 2015. Organic matter content of near the highway soils in Tekirdag province. KSU Journal of Natural Sciences, Special Issue, 18 (3): 49- 53.

Çimrin K, Karaca S, Bozkurt MA. 2000. The effect of NPK and humic acid applications on growth and nutrition of corn plant (Zea mays L.). Journal of Agricultural Sciences, 7: 95100.

David PP, Nelson PV, Sander DC. 1994. Humic acid improves growth of tomato seedling in solution culture. J. of plant Nutrition, 17 (1): 173- 184.

Diwakar BT, Dutta PK, Lokesh BR, Naidu KA. 2010. Physicochemical properties of garden cress (Lepidium sativum L.) Seed Oil, AOCS 87: 539-548.
Doğru A, Darçın ES, Tutar A, Dizman M, Koç Y. 2012. The effect of potassium humate on the growth of maize (Zea mays L.). SAU Journal of Arts and Science 14 (1): 83-93.

Fagbenro JA, Agboola AA. 1993. Effect of different levels of humic acid on the growth and nutrient uptake of teak seedlings. J. of Plant Nutrition 16 (8): 1465- 1483.

Kacar B, İnal A. 2010. Plant Analysis. Nobel Publications No: 849, Ankara.

Karaman MR, Turan M, Tutar A, Dizman M. 2012a. Relationship between humic substances and micro nutrients availability in plant production. SAU Journal of Arts and Science 14 (1): 165- 175.

Karaman MR, Turan M, Yıldırım E, Güneş A, Esringü A, Demirtaş A, Gürsoy A, Dizman M, Tutar A, Kılınç H, 2012b. Determination of effects calcium and boron humate on tomato (Lycopersicon esculentum L.) yield parameters, chlorophyll and stomata conductivity. SAU The Journal of Arts and Science 14 (1): 177- 185.

Naeem M, Iqbal J, Bakhsh MAA. 2006. Comparative study of inorganic fertilizers and organic manures on yield and yield components of mungbean (Vigna radiat L.). J. Agric. Soc. Sci., 2: 227-229.

Tuncay O, Eşiyok D, Yağmur B, Okur B. 2011. Yield and quality of garden cress affected by different nitrogen sources and growing period. Afr. J. Agric. Res. 6(3): 608-617.

Yanmaz R, Yildirim E,Koyuncu D. 2010. A New Garden Cress (Lepidium sativum var. sativum) variety for Turkey: Dadas. J. Agric. Fac. Atatürk Uni. 41 (2): 91-95.

Zhan LJ, Fontana E, Tibaldi G, Nicola S. 2009. Qualitative and physiological response of minimally processed garden cress (Lepidium sativum L.) to harvest handling and storage conditions J. Food Agric. Environ. 7 (3-4): 43-50. 